\title{
Aerial surveys conducted along the Garden Route coastline, South Africa, to determine patterns in shore fishing effort
}

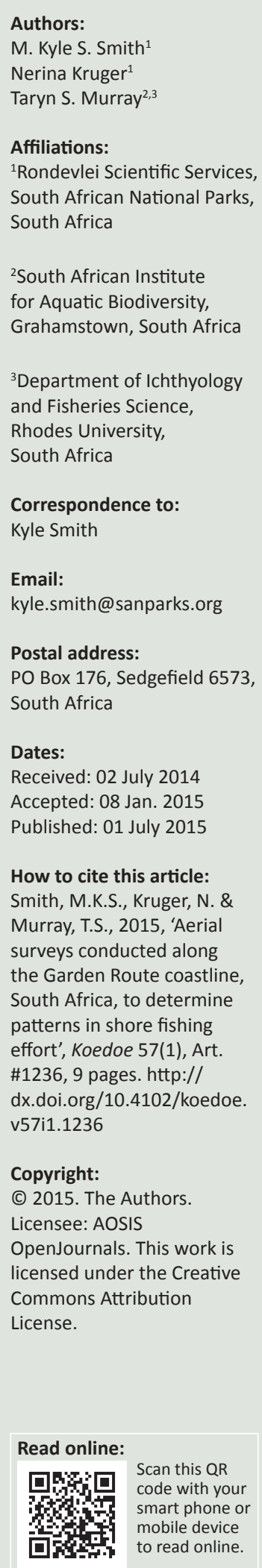

\section{Authors:}

M. Kyle S. Smith

Affiliations:

South African National Parks,

${ }^{2}$ South African Institute

for Aquatic Biodiversity,

${ }^{3}$ Department of Ichthyology

and Fisheries Science,

Rhodes University,

Correspondence to:

Kyle Smith

Email:

Postal address:

PO Box 176, Sedgefield 6573 ,

Dates:

Accepted: 08 Jan. 2015

Murray, T.S., 2015, 'Aerial

surveys conducted alon

South Africa, to determine

patterns in shore fishing

ort', Koedoe 57(1), Art.

dx.doi.org/10.4102/koedoe.

v57i1.1236

Licensee: AOSIS

Commons Attribution

License.

\begin{abstract}
Coastal environments provide a wide range of leisure opportunities, including recreational fishing. Understanding spatial and temporal fishing patterns is important in ensuring wise management and sustainable use. To provide information on shore angler effort and distribution, randomised aerial surveys of the Garden Route coast between the eastern border of the Tsitsikamma Marine Protected Area and the Kaaimans River mouth in the west were undertaken between December 2008 and November 2009. A total of 15 flights were conducted, with six flights taking place over weekends, two on public holidays and the balance on normal week days. Angler effort was not uniformly distributed along the coastline, and spatial analysis highlighted coastal areas both inside and outside marine protected areas that had increased angler effort. In general, fishing effort was highest around more densely populated areas and concentrated in areas with easy access. Although angler counts were highly variable, the seasonality of shore angling effort showed a slight increase during autumn and winter and angling effort was significantly higher on weekends.
\end{abstract}

Conservation implications: Data obtained during these surveys can assist management with future conservation planning exercises, whilst also guiding daily law enforcement patrols to maximise angler encounters.

\section{Introduction}

Coastal environments provide a wide range of recreational opportunities and are highly valued amongst various user groups (James 2000). Understanding recreational use patterns is often necessary for adequate coastal management (Smallwood et al. 2011). In particular, the spatial and temporal distribution of activities can be used in future coastal zoning, whilst also elucidating compliance with current zonation plans. Similarly, a knowledge of resource use patterns can be used by management authorities in planning and optimising when and where law enforcement patrols should take place in order to maximise outputs and minimise costs. Impacts arising from recreational activities depend on several factors, such as the type of activity, the number of participants, and the resilience of different species and habitats to the pressure (Davenport \& Davenport 2006; Meyer \& Holland 2008).

Recreational fishing is a popular activity and can arguably have a large impact through overexploitation and harvesting of select species. Although it is unlikely that a single angler's catch can have a measurable impact on fish populations, the cumulative impacts of (1) the widespread nature of recreational angling, (2) the total number of anglers involved and (3) the defined habitats in which fishing occurs are important factors to consider (Cooke \& Cowx 2004; McPhee, Leadbitter \& Skilleter 2002).

Within the South African shore-based linefishery, overfishing by recreational anglers is seen as a contributing factor to changes that have occurred in the composition of species catch (Bennett 1991; Brouwer \& Buxton 2002; Brouwer et al. 1997; Dunlop \& Mann 2012) and decreases in the abundance of target species (Attwood \& Farquhar 1999; Bennett 1991; Cowley, Brouwer \& Tilney 2002). This has resulted in increased emphasis on marine protected areas (MPAs) as the basis for marine conservation, an essential component for fisheries management in South Africa (Attwood et al. 1997).

The benefits of MPAs typically include the restoration of marine ecosystems and natural ecosystem functioning, increased species diversity, and natural size and age structure of protected fish populations (Halpern 2003). Further fishery benefits include a spillover of subadult and adult fish, and the production of eggs and larvae that can be distributed over a large area (Brouwer et al. 2003; Kerwath et al. 2013; Tilney et al. 1996). However, the effectiveness of MPAs in meeting 


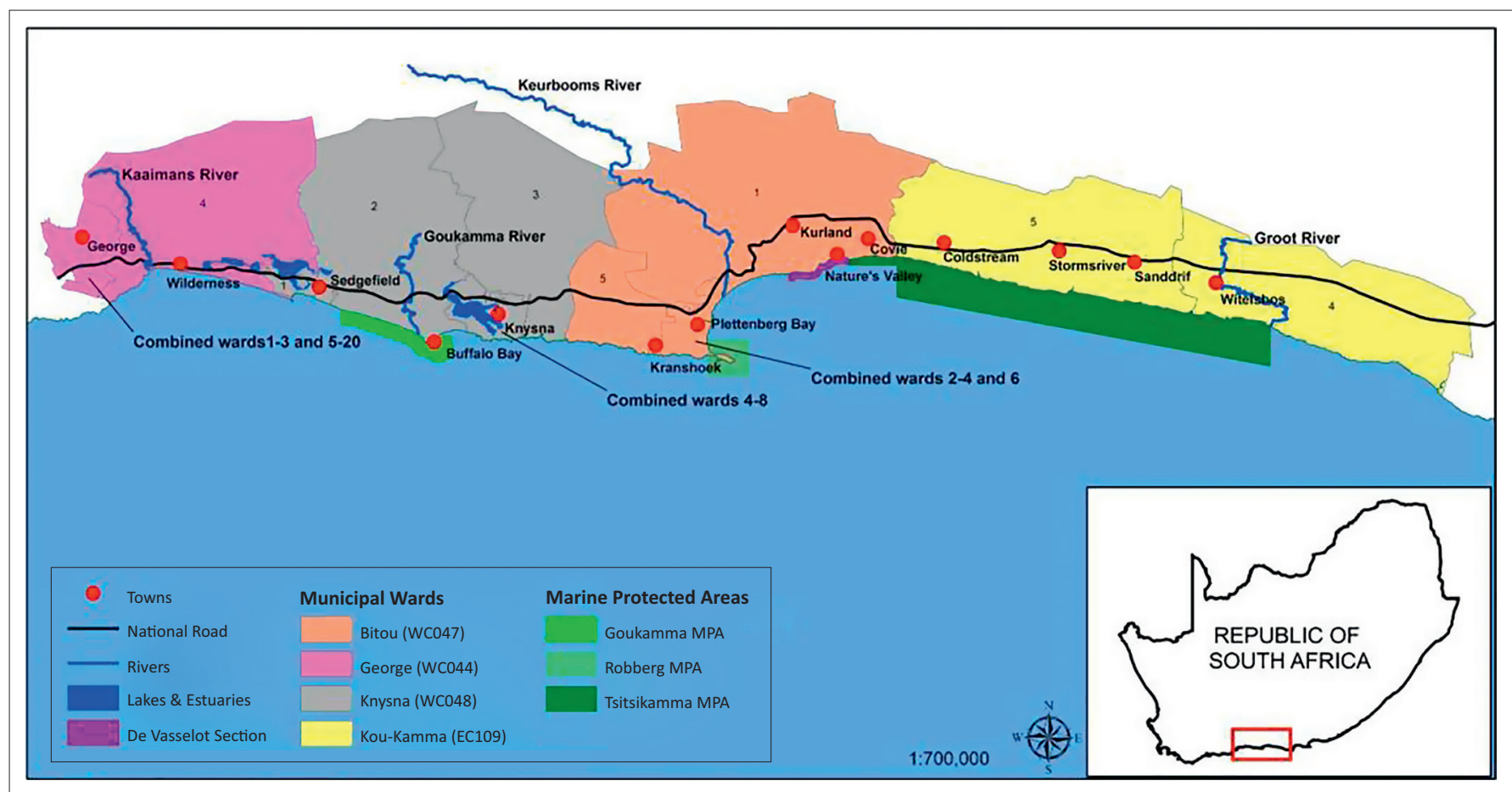

FIGURE 1: A map of South Africa showing the location of the study area along the south coast, and the location of marine protected areas, municipal wards and towns within the study area.

their conservation and fishery objectives is dependent on user compliance, with illegal fishing reducing their efficacy and negatively impacting fishery benefits (Arias \& Sutton 2013). Unfortunately, quantification of non-compliance by recreational anglers is rare, in particular with spatial zonation and over large areas.

During this study, aerial surveys, as an alternative method to traditional on-the-ground or water-based surveys (Brouwer 1997; Mann et al. 2008; Pollock et al. 1994), were used to (1) test the hypothesis that shore angling effort along the Garden Route coastline shows spatial and temporal variation, (2) assess compliance with spatial zoning and (3) provide recommendations to improve the efficiency of law enforcement activities within this area.

\section{Research method and design Study area}

This study was conducted along the Garden Route coastline of South Africa between the Groot River in the east and the western border of the Kaaimans River mouth (Figure 1). The study area consisted of predominantly rocky coastline (78\%) and sandy beaches $(22 \%)$ and was $248 \mathrm{~km}$ long. The area falls under the jurisdiction of four local municipalities, with several towns and villages scattered throughout the adjacent interior. Coastal access points are plentiful. The majority of people living in the area are situated in or near the towns of George, Knysna and Plettenberg Bay (Table 1).

Three MPAs are situated within the study area: The Tsitsikamma MPA consists of $68 \mathrm{~km}$ of closed (no resource use) coastline and forms part of the Garden Route National Park, managed by South African National Parks, whilst
TABLE 1: Population numbers per ward for each of the local municipalities within the study area.

\begin{tabular}{lcccccc}
\hline Municipality & \multicolumn{6}{c}{ Municipal wards } \\
\cline { 2 - 7 } & $\mathbf{1}$ & $\mathbf{2}$ & $\mathbf{3}$ & $\mathbf{4}$ & $\mathbf{5}$ & Other wards \\
\hline Kou-Kamma & - & - & - & 6325 & 6902 & - \\
Bitou & 8119 & - & - & - & 5974 & 23485 \\
Knysna & 6210 & 5793 & 4852 & - & - & 38624 \\
George & 9356 & - & - & 8192 & - & 129253 \\
\hline
\end{tabular}

Source: SA Census 2011

Note: George ward 16 lay outside the study area and has not been included. Other wards include small, higher-density wards within the study site, generally close together and situated around town centres (Bitou wards include wards 2, 3, 4 and 6; Knysna wards include ated around town centres (Bitou wards include wards 2, 3, 4 and 6; Knys

both the Robberg and Goukamma MPAs, managed by CapeNature, are open to shore angling, but no boat angling is permitted.

\section{Methods}

Monthly aerial surveys covering the survey area were conducted between December 2008 and November 2009 in order to obtain 'instantaneous' counts of shore angling effort. Survey days and flight times were randomly selected, but depended on the weather, and pilot and observer availability. All flights were conducted during daylight hours, with the earliest flight taking place at 09:10 and the latest at 15:55. All counts were done in an east-west direction, as the observers were seated on the starboard side of the plane.

The first four surveys were undertaken in a four-seater Robinson helicopter, after which a four-seater Cessna light aircraft was used. Flight parameters, including air speed and altitude, were standardised, but depended on weather conditions and the pilot's discretion. Flight times ranged between $70 \mathrm{~min}$ and $80 \mathrm{~min}$, with an average air speed of $189 \mathrm{~km} \cdot \mathrm{hr}^{-1}$ for both aircraft. Altitude ranged between 
$30 \mathrm{~m}$ a.s.l. and $80 \mathrm{~m}$ a.s.l. for the Robinson and between $150 \mathrm{~m}$ a.s.l. and $250 \mathrm{~m}$ a.s.l. for the Cessna.

On each flight, two observers counted shore anglers and one scribe entered the data into a global positioning systemenabled pocket PC. Each spotter was equipped with a pair of binoculars (10 x 42 magnification) and continuously scanned the coastline, verifying the other spotter's counts. When large groups of anglers were encountered, a second flyby was made and anglers were re-counted by both spotters. Information recorded during the aerial surveys included the date, time, weather, sea conditions, number and location of anglers or boats and habitat where shore anglers were fishing (rock or sand).

Data were also obtained from three aerial surveys conducted in December 2008 as part of a study researching the ecology, value and management of the Garden Route (Chalmers et al. 2009). Methods were similar, with the same Cessna plane and pilot being used, two observers and similar standardised flight speed and altitude. This information was used in temporal, but not spatial (coastal effort maps), analyses.

\section{Analyses}

\section{Aerial survey data maps}

The southern Cape coastline that falls within the study area was buffered by $1 \mathrm{~km}$ to create a polygon representing the area of interest. Spatial mapping of angler effort was plotted using three different coastal breaks. The first method (equal breaks) split the coastline into $10 \mathrm{~km}$ sections. The second method compared the status (MPA or non-MPA) using the layer of the MPAs of the National Spatial Biodiversity Assessment (Lombard et al. 2004). The final method used the coastal breaks described in the Coastal Sensitivity Atlas of Southern Africa (Jackson \& Lipschitz 1984). For this analysis, exposed rocky headlands and wave-cut rocky platforms were combined into one category (rocky).

Aerial survey point data containing angler counts were overlaid onto each coastal break layer and the density of anglers per coastal section for each of the different breaks was calculated as anglers. $\mathrm{km}^{-1}$. Angler effort was depicted in graduated colours for seven natural break classes. KruskalWallis one-way analyses of variance (ANOVAs) were performed to determine if there was a difference in angling effort spatially for each of the three different coastal breaks, and temporally between week and weekend days and seasons.

\section{Effort}

The unit of fishing effort chosen was angler outings, with data pooled seasonally due to unequal sampling effort. Total seasonal fishing effort $\left(\mathrm{E}_{\text {seasonal outings }}\right)$ was calculated using the following formulae:

$\mathrm{E}_{\text {seasonal outings }}=\mathrm{E}_{\mathrm{W} 1}+\mathrm{E}_{\mathrm{W} 2}$

[Eqn 1]

Where $\mathrm{E}_{\mathrm{W} 1}$ and $\mathrm{E}_{\mathrm{W} 2}$ are the weekday and weekend estimates respectively, given by:

$\mathrm{E}_{w j}=\left[\frac{\sum_{i=1}^{\mathrm{n}} e_{i}}{d / p}\right]$

Where $j$ is week days or weekends, $e_{i}$ is the number of anglers on the $i$ th day, $d$ is the number of days sampled and $p$ is the potential number of sampling days.

Total annual fishing effort $\left(\mathrm{E}_{\text {Toutings }}\right)$ was calculated as the sum of the estimated seasonal effort $\left(\mathrm{E}_{\text {seasonal outings }}\right)$ multiplied by a correction factor (2.48) to account for angler turnover.

$\mathrm{E}_{\text {Tountings }}=\sum \mathrm{E}_{\text {seasonal outings }} \times$ turnover rate

[Eqn 3]

Total annual fishing effort $\left(\mathrm{E}_{\text {Toutings }}\right)$ was then multiplied by the average fishing trip duration of anglers interviewed during two ground-based roving creel studies (Smith 2012; Van Zyl 2011).

A Kruskal-Wallis one-way ANOVA was performed to determine if there was a difference in angling effort between seasons, and a Mann-Whitney $U$ test was used to establish if there was a difference in angling effort between week and weekend days.

\section{Results}

A total of 15 aerial surveys were conducted between December 2008 and November 2009 (Table 2), with 6 flights occurring during summer months, 4 in autumn, 3 during winter and 2 in spring. Most flights were conducted in the morning, with 3 weekend flights having being completed during the afternoon.

\section{Spatial patterns in fishing effort}

Angling effort showed a heterogeneous distribution throughout the study area and although variability in count data was high, a significant difference in angling effort occurred between MPAs and non-MPAs (Kruskal-Wallis one-way ANOVA, $d f=6, p$-value $<0.05$ ) (Figure 2) and

TABLE 2: Summary of aerial surveys conducted each month, grouped seasonally and stratified according to week or weekend day.

\begin{tabular}{|c|c|c|c|c|c|c|c|c|c|c|c|}
\hline \multirow[t]{2}{*}{ Day type } & \multicolumn{3}{|c|}{ Summer } & \multicolumn{3}{|c|}{ Autumn } & \multicolumn{3}{|c|}{ Winter } & \multicolumn{2}{|c|}{ Spring } \\
\hline & Dec. $\dagger$ & Jan. & Feb. & Mar. & Apr. & May & June & July & Aug. & Sept. & Nov. \\
\hline \multirow[t]{2}{*}{ Week } & $\mathrm{am}$ & - & am & - & am & am & - & am & - & - & am \\
\hline & - & - & am & - & - & - & - & - & - & - & - \\
\hline \multirow[t]{2}{*}{ Weekend } & am & - & $\mathrm{pm}$ & $\mathrm{pm}$ & am & - & - & am & am & am & - \\
\hline & $\mathrm{am}$ & - & - & - & - & - & - & $\mathrm{pm}$ & - & - & - \\
\hline
\end{tabular}

Source: †, Aerial surveys conducted by Chalmers, R., Bennett, R.H., Turpie, J.K., Andrew, M., Andrew, T., Clark, B.M. et al., 2009, 'Ecology, value and management of the Garden Route coast', report prepared for WWF-CAPE Marine Programme, South Africa 


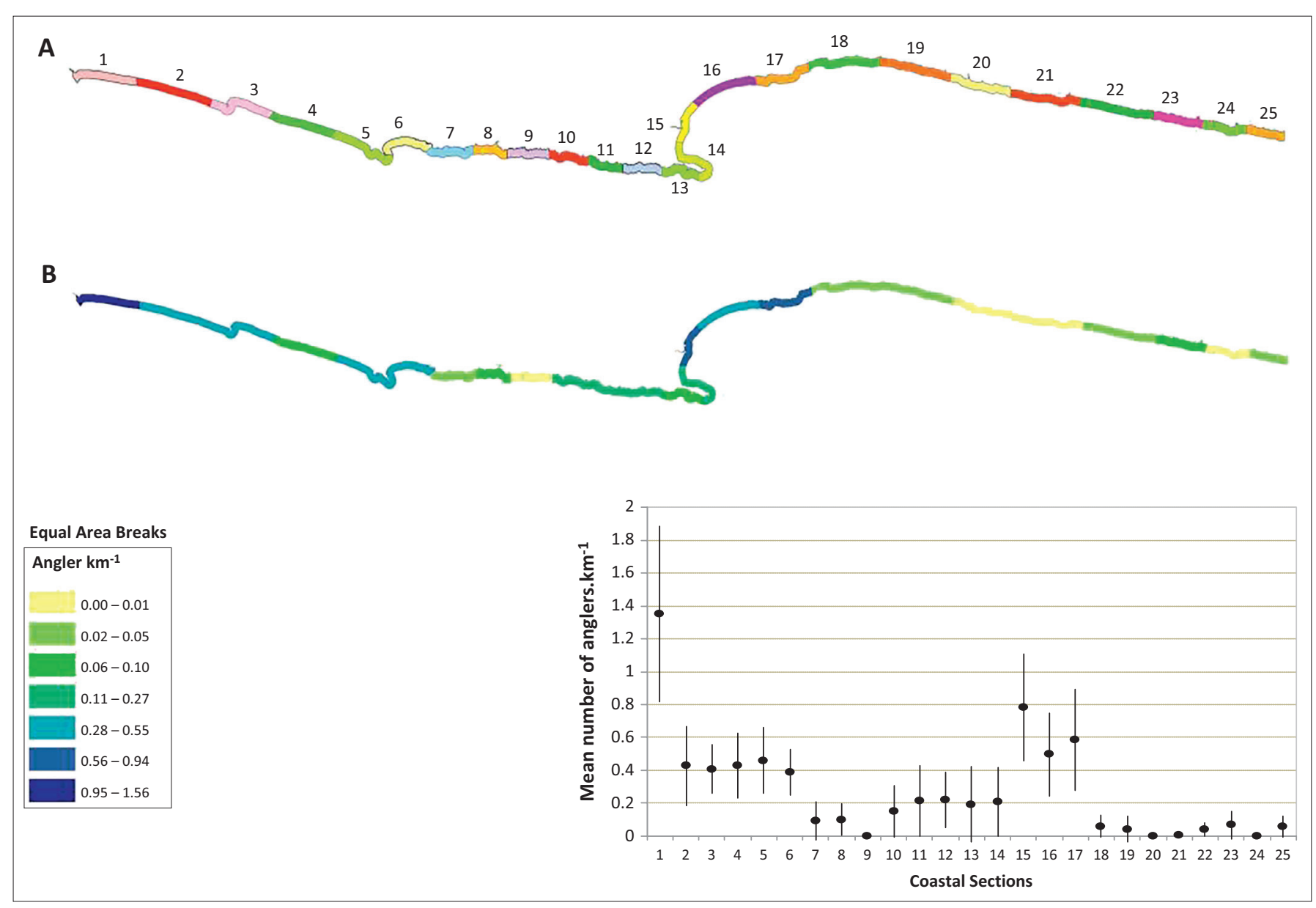

FIGURE 2: The South African Garden Route coastal section broken into equal areas (A) and the spatial distribution of total angling effort (anglers.km ${ }^{-1}$ ) between Kaaimans River in the west and the eastern border of the Tsitsikamma Marine Protected Area at the Groot River (B). Up-down bars indicate the $95 \%$ confidence interval.

equal area breaks (Kruskal-Wallis one-way ANOVA, $d f=24$, $p$-value < 0.05) (Figure 3).

The majority of anglers (72.50\%) fished in open access areas outside formal conservation borders (including no-take and controlled zones) and a Bonferroni post-hoc test showed that the Tsitsikamma MPA had significantly less fishing effort than all other sections ( $p$-value $<0.05$ ) with the exception of zone 9 , in which no anglers were encountered. Although the Tsitsikamma MPA is zoned for no-take (i.e. no consumptive use), a total of 32 illegal fishermen were counted during all the surveys, with an overall angler density of 0.03 anglers. $\mathrm{km}^{-1}$ (Figure 3).

Outside of formal protected areas, the highest density of anglers occurred in section one (Wilderness) with 1.35 anglers. $\mathrm{km}^{-1}$, followed by section 15 (Plettenberg Bay) and 17 (Nature's Valley) with overall angler densities of 0.78 anglers. $\mathrm{km}^{-1}$ and 0.58 anglers. $\mathrm{km}^{-1}$ respectively (Figure 2). These three sections contributed to the overall angler densities being highest ( 0.73 anglers. $\left.\mathrm{km}^{-1}\right)$ along the larger section of coastline between the Kaaimans River mouth and the western border of the Goukamma MPA. This was followed by the Plettenberg Bay coastline (Robberg to De Vasselot) with 0.65 anglers. $\mathrm{km}^{-1}$ and the De Vasselot section of the Garden Route National Park with the third highest density of 0.51 anglers. $\mathrm{km}^{-1}$ (Figure 3). The Goukamma and Robberg MPAs had overall angler densities of 0.41 anglers. $\mathrm{km}^{-1}$ and 0.14 anglers. $\mathrm{km}^{-1}$ respectively (Figure 3 ), whilst the coastal section between the Goukamma and Robberg MPAs, consisting of large stretches of exposed rocky coastline with few access points, had a relatively low overall angler density of 0.16 anglers. $\mathrm{km}^{-1}$.

Angling effort occurred on both rocky and sandy substrates throughout the study area with both high densities (2.23 anglers. $\mathrm{km}^{-1}-3.94$ anglers. $\mathrm{km}^{-1}$ ) occurring over rocky (Figure 4a) and sandy substrates (Figure 4b). Although total angler density on rocky substrates was lower $\left(0.31\right.$ anglers. $\left.\mathrm{km}^{-1}\right)$ than on sandy substrates $\left(0.47\right.$ anglers. $\left.\mathrm{km}^{-1}\right)$, fishing effort between substrates was not significantly different (Mann-Whitney $U$ test, $p$-value 0.221 ).

\section{Temporal patterns in fishing effort}

Although more anglers were encountered during the autumn (0.37 anglers. $\left.\mathrm{km}^{-1}\right)$ and winter $\left(0.38\right.$ anglers. $\left.\mathrm{km}^{-1}\right)$ months (Figure 5a), with fewer anglers fishing in spring $(0.20$ anglers. $\left.\mathrm{km}^{-1}\right)$ and summer (0.21 anglers. $\left.\mathrm{km}^{-1}\right)$, no significant difference was observed (Kruskal-Wallis one-way ANOVA, $d f=3, p$-value 0.266 ). This was due to the high variability within the data, exacerbated by the low sample size. Fishing pressure was significantly higher during weekends and public holidays (0.38 anglers. $\mathrm{km}^{-1}$ ) than on week days 


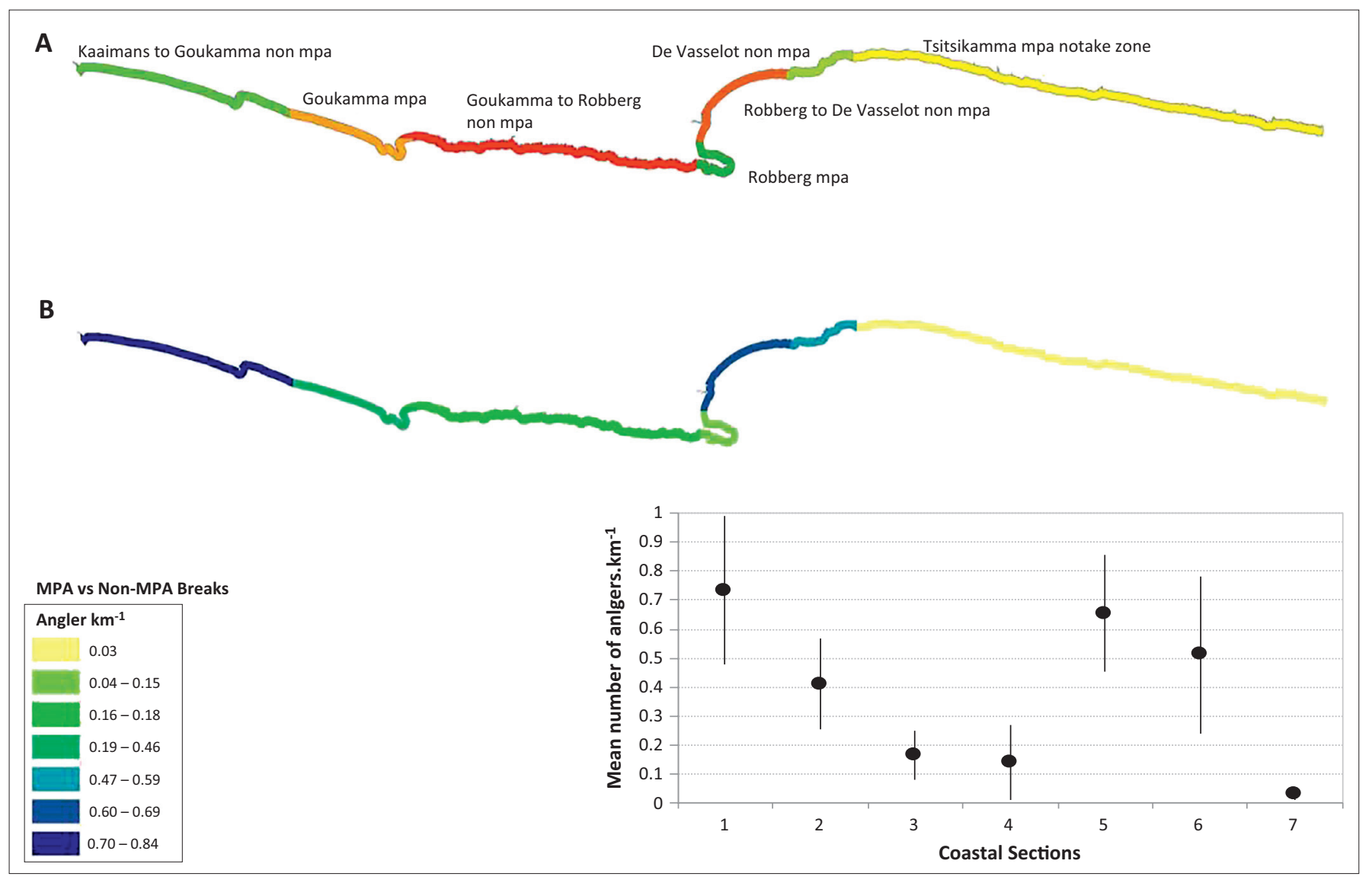

MPA, marine protected area; Non-MPA Breaks, non-marine protected area breaks.

FIGURE 3: The South African Garden Route coastal section divided into marine protected areas and open areas (A) and the spatial distribution of total angling effort (anglers. $\mathrm{km}^{-1}$ ) within marine protected areas and open areas between the Kaaimans River in the west and the eastern border of the Tsitsikamma Marine Protected Area at the Groot River (B). Up-down bars indicate the $95 \%$ confidence interval.

$\left(0.18\right.$ anglers. $\left.\mathrm{km}^{-1}\right)$ (Mann-Whitney $U$ test, $d f=1, p$-value 0.028) (Figure 5b).

\section{Total angling effort}

Total annual shore angling effort was estimated at 49812 angler outings. Recent angler interviews conducted along portions of this coastline indicate that anglers spend on average between 5 hours (Smith 2012) and 6 hours (Van Zyl 2011) fishing per outing. Using these figures, a total annual fishing effort estimate was estimated to be between 226645 angler hours and 298872 angler hours.

\section{Discussion}

Assessing spatio-temporal resource use patterns is important when implementing fishery and conservation management practices. This information can help with future conservation and spatial planning exercises by highlighting areas from which anglers may be displaced or, conversely, areas where no fishing activity occurs and which may act as natural spatial harvest refugia for target species (Smallwood \& Beckley 2012). Furthermore, identifying popular fishing locations can allow management authorities to maximise resource allocation and streamline daily law enforcement operations (Smallwood \& Beckley 2012).

\section{Spatio-temporal patterns in fishing activity}

Angler distribution is unlikely to be uniformly distributed along any coastline and may be impacted by access points and infrastructure that have a clustering effect (Smallwood et al. 2012). Similarly, habitat preferences of target fish species can influence the spatial distribution of anglers attracted to particular sites and different species (Smallwood et al. 2013).

Recreational fishing along the Garden Route coastline showed a heterogeneous spatial distribution, with some localised areas having high angler densities. These areas were generally associated with ease of access and proximity to the more heavily populated urban areas of George and Plettenberg Bay. A similar pattern was shown along the KwaZulu-Natal coast of South Africa (Mann et al. 2008), where angler effort was largely concentrated around access points, with increased effort along the more developed and highly populated sections of the coastline. The concentration of anglers around easy access points along South Africa's coastline has more than likely been heightened by the 2002 ban (Schedule 44 of the National Environmental Management Act [Act No. 107 of 1998]) on beach driving, which limits anglers' access to the more remote sections of coastline (Mann \& Tyldesley 2012; Mann et al. 2008). 


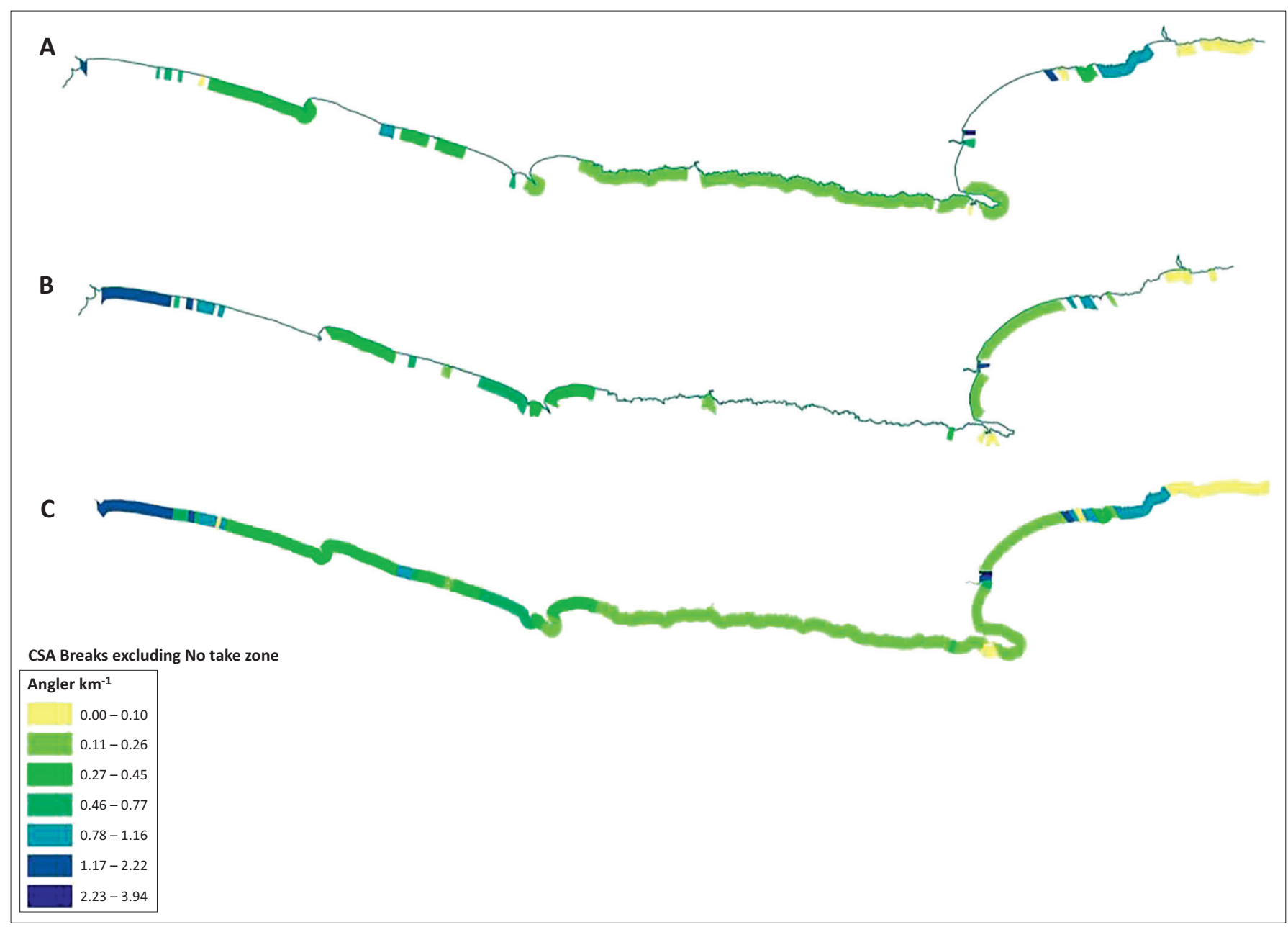

CSA, coastal sensitivity areas.

FIGURE 4: The distribution of total angling effort (anglers. $\mathrm{km}^{-1}$ ) between the Kaaimans River in the west and the western border of the no-take Tsitsikamma Marine Protected Area between rocky areas (A), sandy areas (B) and both rocky and sandy areas combined (C).

In fisheries where angling effort is widely dispersed (e.g. coastlines), instantaneous estimates of total fishing effort obtained from aerial surveys are more accurate and preferable to land-based roving creel surveys (Pollock et al. 1994). Although no previous aerial surveys have been undertaken along this section of coastline for comparative purposes, a number of land-based roving creel surveys covering sections of the coastline have been completed, including Plettenberg Bay (King 2006), the Goukamma MPA (Van Zyl 2011) and the Wilderness to Sedgefield coastline (Smith 2012). These projects, conducted at finer spatial scales, show similar patterns and general trends to those recorded during the aerial surveys conducted in this study.

Greater angling effort (1.03 anglers. $\left.\mathrm{km}^{-1}\right)$ was recorded along the Wilderness to Sedgefield (Smith 2012) and Plettenberg Bay coastlines (0.71 anglers. $\mathrm{km}^{-1}$ [King 2006]) during land-based surveys, in comparison to 0.84 anglers. $\mathrm{km}^{-1}$ and 0.69 anglers. $\mathrm{km}^{-1}$ recorded during the aerial surveys of this study. Due to the generally shorter distance and slower speed of land-based creel surveys, a higher estimation of effort in comparison to aerial surveys would be expected (Pollock et al. 1994). The Goukamma study did not report on angler densities in terms of anglers. $\mathrm{km}^{-1}$ of coastline, but estimated total effort relating to angler hours (21 428 [Van Zyl 2011]), approximately half the 48167 angler hours estimated in the Wilderness study (Smith 2012). This is similar to the trend seen in the effort estimations of the aerial surveys, with an overall angler density of 0.46 anglers. $\mathrm{km}^{-1}$ recorded for the Goukamma MPA.

The distribution and density of recreational users in general is known to be impacted by large temporal factors such as seasons and holiday periods (Hingham \& Hinch 2002). Large-scale patterns in recreational shore fishing along the South African east coast have also been shown to fluctuate seasonally, with an increase in summer and a decrease in winter (Brouwer et al. 1997). Both King (2006) and Smith (2012) have shown that recreational shore fishing within Plettenberg Bay and the Wilderness coastline followed this trend, attributing the increase in effort to an influx of visitors during school holiday periods. However, results from the aerial surveys are more consistent with those from Goukamma (Van Zyl 2011) and the KwaZulu-Natal shore fishery (Dunlop \& Mann 2012; Mann et al. 2008), which both showed an increase in shore angling density over the winter months.

Two popular targeted shore angling species, galjoen (Dichistius capensis) and elf (Pomatomus saltatrix), show 

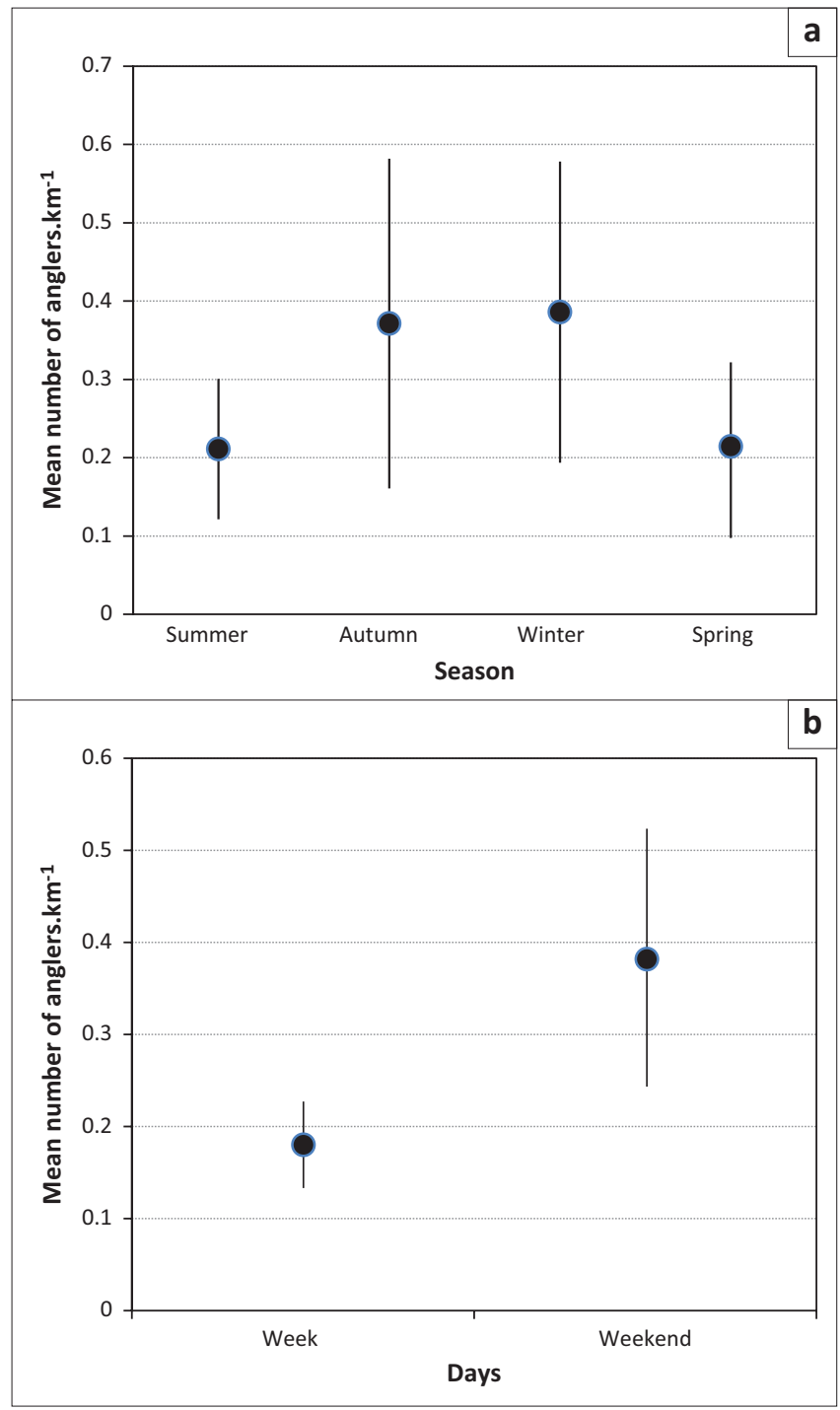

FIGURE 5: Mean shore angling effort (anglers. $\mathrm{km}^{-1}$ ) (a) seasonally and (b) during week and weekend days along the South African Garden Route coast between December 2008 and November 2009 (public holiday counts were included as weekend days).

strong seasonal abundance and have closed seasons between 15 October and the last day in February, and 01 October and 30 November respectively. It is thus likely that those anglers who specifically target these species are temporarily absent from the fishery during these closed periods (Mann et al. 2008; Van Zyl 2011).

Given that no previous aerial surveys have been conducted along the Garden Route coastline and shore-based surveys have only covered portions of the coastline, it is impossible to say whether total fishing effort is increasing or not. A decrease in shore-based angling effort along the KwaZuluNatal coastline (Dunlop \& Mann 2012) has been attributed to security concerns, declining catches, an increase in the cost of fishing and stricter linefish regulations. As catch rates within the shore fishery have decreased (Brouwer \& Buxton 2002), the duration and frequency of fishing may have altered, which in turn would affect the turnover rate used to calculate the total estimated effort. However, the current average fishing duration of between 5 hours (Smith 2012) and 6 hours (Van Zyl 2011) is very similar to the 5 hours calculated 15 years earlier (Brouwer 1997). Independent effort calculations are seen as a crucial part of the management and monitoring of the South African shore fishery (Dunlop \& Mann 2012) and the total angling effort estimated from this study provides a baseline for future work.

\section{Non-compliance with spatial closures}

With greater biodiversity and abundance of fish, MPAs where fishing is allowed are attractive locations for recreational anglers (Cooke et al. 2006; Götz, Cowley \& Winker 2008; Parker, Booth \& Mann 2013). However, non-compliance by anglers fishing in closed, no-take areas can undermine conservation and fishery management objectives. Along the Garden Route, shore fishing is allowed in all MPAs except Tsitsikamma. However, illegal shore fishing (poaching) was observed on several occasions during this study within the no-take Tsitsikamma MPA. Although fishing levels inside the park were low compared to outside adjacent areas, illegal fishing within this important MPA is cause for concern.

Within the Ningaloo Marine Park in North West Australia, anglers were found to be concentrated in localised areas with easy access, and limited non-compliance was observed within no-take zones (Smallwood et al. 2011). The low levels of non-compliance were attributed to a number of factors, including (1) multiple educational tools (signboards and brochures), (2) visual zonation reference points, (3) various enforcement patrols (boat- and land-based) and (4) a willingness by anglers to fish at alternative sites (Smallwood \& Beckley 2012). More research is required regarding the illegal fishing taking place within the Tsitsikamma MPA to gain a greater understanding of the extent of this activity and the underlying drivers, which could then be used by management to address and resolve this issue.

Although the Goukamma and Robberg MPAs are open to shore-based fishing, these areas had comparatively lower angler densities than other sections of coastline outside the formal conservation areas. Fishing locations within Robberg are limited due to a large seal colony on the eastern side and the exposed rocky coastline on the west, restricting fishing to a few well-known locations (King 2005). The Goukamma MPA has a combination of habitat types and land-based roving creel surveys conducted within this reserve (Van Zyl 2011) showed that anglers were clustered around easily accessible areas, favouring rocky and mixed shores over sandy beaches. Similar to the aerial survey data presented here, angler densities were greater around the Buffalo Bay section of the reserve, which may be due to ease of access, with anglers in the Goukamma section having to walk up to $6 \mathrm{~km}$ to reach some fishing locations.

\section{Limitations of the study}

Surveys to provide information on spatial and temporal patterns of resource use need to be designed and implemented at appropriate scales. Numerous access points, the longitudinal and rugged nature of coastlines and the 
size of management areas complicate survey design. Aerial surveys can be an effective technique for obtaining spatial and temporal data on recreational activities, including fishing, over a broad landscape (Pollock et al. 1994). Such surveys are cost-effective and efficient, with minimal personnel involved and can cover large geographic areas in a relatively short time (Malvestuto 1983).

To avoid sampling biases, flights must be random in terms of direction, time of day and type of day (week or weekend) (Pollock et al. 1994). In practice this becomes difficult, with weather conditions in particular playing an important role in determining flight days. The greatest limitation of this study was the inability to keep sampling effort equal between months, with flights conducted on both week and weekend days. Subsequently, monthly estimates of angler effort and comparisons were not possible. Analysing the data by season to estimate total angler effort attempts to alleviate this issue to some extent, but an unknown degree of error is being introduced and needs to be acknowledged.

Spatial accuracy of observed data points was improved through the use of data loggers that automatically recorded time and positional information, enabling the observers to simply record numbers and substrate. Prominent landmarks were also geo-referenced prior to the aerial flights, providing a known position that could be recorded, eliminating sampling errors associated with fishing at these points. However, visibility bias and in particular difficulty in seeing anglers on rocky sections of coastline may have led to an underestimation of total angling effort. Ground truthing of counts would be important for future surveys.

\section{Conclusion}

Aerial surveys are a useful and well-established method of collecting data across large spatial scales. These data can be used in both future planning exercises and also in determining the success of current management plans and policies (e.g. non-compliance with spatial zoning).

Although our ability to estimate total angler effort from the current data set is limited due to unequal monthly sampling effort, results from this study showed temporal trends with seasonal fluctuations for recreational fisheries. An increase in effort over weekends and public holidays was evident, whilst broad-scale spatial patterns were similar to results from more in-depth, land-based projects.

In general, fishing effort was highest around the more heavily populated areas of George and Plettenberg Bay and concentrated in areas with easy access. Should aerial surveys be implemented again, care should be taken to ensure equal monthly effort (i.e. flights should be conducted at least bi-monthly - on one weekday and one weekend day or public holiday), with flight scheduling incorporating back-up days for bad weather and mechanical problems. The value of surveys could be further increased by collecting data on other types of coastal resource use, such as bait harvesting.

The findings of this study have relevance to the management of the fishery along the Garden Route coastline in guiding the deployment of fisheries management field personnel, both spatially and temporally, to maximise contact with fishers and therefore improve levels of compliance.

\section{Acknowledgements}

Funding for the flights was made available through the National Marine Protected Area budget, allocated to the South African National Parks by the Department of Environmental Affairs. We thank the volunteers and pilots who assisted during the aerial surveys and two anonymous reviewers for their positive contributions towards this manuscript.

\section{Competing interests}

The authors declare that they have no financial or personal relationships which may have inappropriately influenced them in writing this article.

\section{Authors' contributions}

M.K.S.S. (South African National Parks) was responsible for the study conceptualisation, data collection, analyses, report writing and editing. N.K. (South African National Parks) contributed to the study design, data collection, GIS analyses, report writing and editing, and T.S.M. (South African Institute for Aquatic Biodiversity) contributed to the study design, data collection, report writing and editing.

\section{References}

Arias, A. \& Sutton, S.G., 2013, 'Understanding Recreational Fishers' compliance with No-take Zones in the Great Barrier Reef Marine Park', Ecology and Society 18(4), 18. http://dx.doi.org/10.5751/ES-05872-180418

Attwood, C.G. \& Farquhar, M., 1999, 'Collapse of linefish stocks between Cape Hangklip and Walker Bay, South Africa', South African Journal of Marine Science 24, 151-160. http://dx.doi.org/10.2989/025776102784528448

Attwood, C.G., Mann, B.Q., Beaumont, J. \& Harris, J.M., 1997, 'Review of the state of marine protected areas in South Africa', South African Journal of Marine Science 18, 341-367. http://dx.doi.org/10.2989/025776197784160910

Bennett, B.A., 1991, 'Conservation in the Marine Environment: Some problems with management of shore-angling in the Southwestern Cape', South African Journal of Aquatic Science 17, 12-18. http://dx.doi.org/10.1080/10183469.1991.9631309

Brouwer, S.L. \& Buxton, C.D., 2002, 'Catch and effort of the shore and skiboat linefisheries along the South African Eastern Cape coast', South African Journal of Marine Science 24, 341-354. http://dx.doi.org/10.2989/025776102784528286

Brouwer, S.L., 1997, 'An assessment of the South African East Coast Linefishery from Kei Mouth to Stil [sic] Bay', MSc Thesis, Department of Ichthyology and Fisheries Science, Rhodes University, Grahamstown.

Brouwer, S.L., Griffiths, M.H. \& Roberts, M.J., 2003, 'Adult movement and larval dispersal of Argyrozona argyrozona (Pisces: Sparidae) from a temperate marine protected area', African Journal of Marine Science 25, 395-402. http://dx.doi. protected area, African Journal of
org/10.2989/18142320309504028

Brouwer, S.L., Mann, B.Q., Lamberth, S.J., Sauer, W.H.H. \& Erasmus, C., 1997, 'A survey of the South African shore-angling fishery', South African Journal of Marine Science 18, 165-177. http://dx.doi.org/10.2989/025776197784161126

Chalmers, R., Bennett, R.H., Turpie, J.K., Andrew, M., Andrew, T., Clark, B.M. et al., 2009, 'Ecology, value and management of the Garden Route coast', report prepared for WWF-CAPE Marine Programme, South Africa.

Cooke, S.J. \& Cowx, I.G., 2004, 'The role of recreational fishing in global fish crises', BioScience 54, 857-859. http://dx.doi.org/10.1641/0006-3568(2004)054[0857: TRORFI]2.0.CO;2

Cooke, S.J., Danylchuk, A.J., Danylchuk, S.E., Suski, C.D. \& Goldberg, T.L., 2006 'Is catch-and-release recreational angling compatible with no-take marine protected areas?', Ocean and Coastal Management 49, 342-354. http://dx.doi. org/10.1016/j.ocecoaman.2006.03.003 
Cowley, P.D., Brouwer, S.L. \& Tilney, R.L., 2002, 'The role of the Tsitsikamma National Park in the management of four shore-angling fish along the south-eastern Cape coast of South Africa', South African Journal of Marine Science 24, 27-35. http:// dx.doi.org/10.2989/025776102784528664

Davenport, J. \& Davenport, J.L., 2006, 'The impact of tourism and personal leisure transport on coastal environments: a review', Estuarine, Coastal and Shelf Science 67, 280-292. http://dx.doi.org/10.1016/j.ecss.2005.11.026

Dunlop, S.W. \& Mann, B.Q., 2012, 'An assessment of participation, catch and effort in the KwaZulu-Natal shore-based marine linefishery, with comments on management effectiveness', African Journal of Marine Science 34, 479-496. http://dx.doi.org/10.2989/1814232X.2012.725526

Götz, A., Cowley, P.D. \& Winker, H., 2008, 'Selected fishery and population parameters of eight shore-angling species in the Tsitsikamma National Park no-take marine reserve', African Journal of Marine Science 30, 519-532. http://dx.doi. org/10.2989/AJMS.2008.30.3.7.641

Halpern, B.S., 2003, 'The impact of marine reserves: Do reserves work and does reserve size matter?', Ecological Applications 13(1), 117-137. http://dx.doi. org/10.1890/1051-0761(2003)013[0117:TIOMRD]2.0.CO;2

Hingham, J. \& Hinch, T., 2002, 'Tourism, sport and seasons: the challenges and potential of overcoming seasonality in the sport and tourism sectors', Tourism Management 23(2), 175-185. http://dx.doi.org/10.1016/S0261-5177(01) 00046-2

Jackson, L.F. \& Lipschitz, S., 1984, 'Coastal Sensitivity Atlas of Southern Africa', compiled for the Department of Transport, Charts 16-18, National Book Printers, Goodwood, Cape Town.

James, R.J., 2000, 'From beaches to beach environments: linking the ecology, humanuse and management of beaches in Australia', Ocean \& Coastal Management 43(6), 495-514. http://dx.doi.org/10.1016/S0964-5691(00)00040-5

Kerwath, S.E., Winker, H., Götz, A. \& Attwood, C.G., 2013, 'Marine protected area improves yield without disadvantaging fishers', Nature Communications 4, 2347. http://dx.doi.org/10.1038/ncomms3347

King, C.M., 2005, 'Towards a new approach for coastal governance with an assessment of the Plettenberg Bay shore-based linefishery', MSc Thesis, Department of Ichthyology and Fisheries Science, Rhodes University, Grahamstown.

Lombard, A.T., Strauss, T., Harris, J., Sink, K., Attwood, C. \& Hutchings, L., 2004 South African National Spatial Biodiversity Assessment 2004: Technical Report, Volume 4: Marine Component, South African National Biodiversity Institute, Pretoria.

Malvestuto, S.P., 1983, 'Sampling the recreational fishery', in L.A. Nielsen \& D.L. Johnson (eds.), Fisheries Techniques, pp. 397-419, American Fisheries Society, Bethesda, Maryland.

Mann, B.Q. \& Tyldesley, M., 2012, 'Monitoring the recovery of a previously exploited surf-zone habitat in the St Lucia Marine Reserve using a no-take sanctuary area as a benchmark', in C. Attwood, T. Booth, S. Kerwath, B. Mann, S. Marr, J. Duncan et al. (eds.) 'A Decade After the Emergency: The Proceedings of the 4th Linefish Symposium', pp. 115-127, WWF South Africa Report Series - 2013/Marine/001.

Mann, B.Q., Nanni, G. \& Pradervand, P., 2008, 'A monthly aerial survey of the KwaZuluNatal marine shore fishery', unpublished report, Oceanographic Research Institute, Durban.

McPhee, D.P., Leadbitter, D. \& Skilleter, G.A., 2002, 'Swallowing the Bait: Is Recreational Fishing in Australia Ecologically Sustainable?', Pacific Conservation Biology 8(1), 40-51.

Meyer, C.G. \& Holland, K.N., 2008, 'Spatial dynamics and substrate impacts of recreational snorkelers and SCUBA divers in Hawaiian Marine Protected Areas', Journal of Coastal Conservation 12, 209-216. http://dx.doi.org/10.1007/s11852009-0043-1

Parker, D., Booth, A.J. \& Mann, B.Q., 2013, 'A spatio-temporal assessment of the Trachinotus botla shore-fishery in KwaZulu-Natal, South Africa', African Journal of Marine Science 35, 35-46. http://dx.doi.org/10.2989/1814232X.2013. 769908

Pollock, K.H., Jones, C.M. \& Brown, T.L., 1994, 'Angler survey methods and their applications in fisheries management', American Fisheries Society Special Publication 25, 135-164.

Smallwood, C.B. \& Beckley, L.E., 2012, 'Spatial distribution and zoning compliance of recreational fishing in Ningaloo Marine Park, north-western Australia', Fisheries Research 125-126, 40-50. http://dx.doi.org/10.1016/j.fishres.2012.01.019

Smallwood, C.B., Beckley, L.E. \& Moore, S.A., 2013, 'Influence of zoning and habitats on the spatial distribution of recreational activities in a multiple-use marine park', Coastal Management 40(4), 381-400. http://dx.doi.org/10.1080/089207 53.2012.692312

Smallwood, C.B., Beckley, L.E., Moore, S.A. \& Kobryn, H.T., 2011, 'Assessing patterns of recreational use in large marine parks: A case study from Ningaloo Marine Park, Australia', Ocean \& Coastal Management 54, 330-340. http://dx.doi. org/10.1016/j.ocecoaman.2010.11.007

Smith, M.K.S., 2012, 'Garden Route National Park - Wilderness Section Coastal Marine Resource Use Monitoring Programme', Scientific Report Number 05/2012, South African National Parks, Skukuza.

SuperWEB by Space Time Research, n.d., viewed April 2014, from http://interactive. statssa.gov.za/superweb/login.do

Tilney, R.L., Nelson, G., Radloff, S.E. \& Buxton, C.D., 1996, 'Ichthyoplankton distribution and dispersal in the Tsitsikamma National Park marine reserve, South Africa', South African Journal of Marine Science 17, 1-14. http://dx.doi. org/10.2989/025776196784158482

Van Zyl, C., 2011, 'The use of a Roving Creel Survey to monitor exploited coastal fish species in the Goukamma Marine Protected Area, South Africa', MTech Thesis, Nelson Mandela Metropolitan University, Port Elizabeth. 